Review Article

\section{Molybdenum potential vital role in plants metabolism for optimizing the growth and development}

\author{
Muhammad Shoaib Rana ${ }^{1,2}$, Parashuram Bhantana ${ }^{1-3}$, \\ Muhammad Imran ${ }^{4}$, Muhammad Hamzah Saleem ${ }^{5}$, \\ Mohamed G Moussa', ${ }^{1,2}$ Zaid Khan', Imran Khan', Mufid \\ Alam $^{6}$, Muhammad Abbas ${ }^{7,8}$, Rana Binyamin ${ }^{9}$, Javaria \\ Afzal ${ }^{1,2}$, Muhamad Syaifudin ${ }^{1,2}$, Intisar Ud Din ${ }^{1,2}$, Muhammad \\ Younas $^{1,2}$, Ilyas Ahmad ${ }^{10}$, Md Ashrafuzzaman Shah ${ }^{1,2}$ and \\ Chengxiao $\mathrm{Hu}^{1,2 *}$
}

${ }^{1}$ Key Laboratory of Arable Land Conservation (Middle and Lower Reaches of Yangtze River), Ministry of Agriculture, Micro-elements Research Center, College of Resource and Environment, Huazhong Agricultural University, Wuhan 430070, China

${ }^{2}$ Hubei Provincial Engineering Laboratory for New Fertilizers, Huazhong Agricultural University, Wuhan 430070, China

${ }^{3}$ Agricultural Research Station, Pakhribas, Dhankuta, Nepal, Agricultural Research Council, Nepal ${ }^{4}$ Department of Crop Science and Technology, College of Agriculture, South China Agricultural University, Guangzhou 510642, PR China

${ }^{5} \mathrm{MOA}$ Key Laboratory of Crop Ecophysiology and Farming in the Middle Reaches of Yangtze River, College of Plant Science and Technology

${ }^{6}$ National Key Laboratory of Crop Genetic Improvement, College of Life Science and Technology, Huazhong Agricultural University, Wuhan 430070, China

${ }^{7}$ Nuclear Institue of Agriculture, Tandojam, Pakistan

${ }^{8}$ Institute of Agriculture Resources and Regional Planning (IARRP), Chinese Academy of Agricultural Sciences (CASS), Beiing, China

'University of Agriculture Faisalabad Sub Campus Burewala Vehari, Pakistan

${ }^{10}$ Soil and Water Testing Laboratory for Research, Multan, Pakistan
Received: 01 June, 2020

Accepted: 16 June, 2020

Published: 17 June, 2020

*Corresponding author: Chengxiao Hu, Professor, Key Laboratory of Arable Land Conservation (Middle and Lower Reaches of Yangtze River), Ministry of Agriculture, Micro-elements Research Center, College of Resource and Environment, Huazhong Agricultural University, Wuhan 430070, China, Tel: (+977) 9849991998; +86 27 87288730; E-mail: hucx@mail.hzau.edu.cn; hailstormsea@gmail.com

Keywords: Molybdenum cofactor; Nitrate reductase; Molybdate transporter; Molybdo-enzymes; Redox behavior

https://www.peertechz.com

Check for updates 


\section{Abstract}

Molybdenum importance for appropriate plant functioning and growth is inconsistent by the most of the plants in respect to the total quantity that is obligatory for them. Molybdenum is a micronutrient that is directly involved in the metabolic functions of nitrogen in the plant. The transition metal molybdenum, in molybdate form, is essential for plants as a number of enzymes use it to catalyze most important reactions in the nitrogen acclimatization, the synthesis of the phytohormone, degradation of the purine and the detoxification of the sulfite. There are more than known 50 different enzymes that need Mo, whether direct or indirect impacts on plant growth and development, primarily phytohormones and the N-metabolism involving processes. On the other hand, in the synthesis of ABA uniquely Moco is involved, there on the level of ABA Moco effect is highly vital and ultimately by the response in the stress and the stomatal control, it has a very important role in the rate of transpiration and water relations. The practices that are involved in the fertilization of Mo optimization in crops, has a very important scope in discovering and improving these practices where the legumes are fixing the $\mathrm{N}_{\text {or }} \mathrm{NO}_{3}^{-}$is primarily source of available $\mathrm{N}$. The deficiency of Mo and to enhance the molybdoenzymes activity, it may be very effective and vital important to use the spray of Mo as foliar application through the soil. The most recent understanding that from the soil how the plant gets access Mo or how they redistribute it is not still clear. However in the system f prokaryotes, it has been found that in plants it has likewise physiological Mo transport phenotypes. So, the mechanism of transport of Mo in the prokaryotes is needed as well as the reconsideration of anion transport mechanism that is in plants, will provide a help to solve that how this is accumulated. In this review, the discussion covers about the vital importance of Mo to enhance the productivity for optimizing the yield concentrating on metabolism, uptake, transport, storage, Mo cofactors, application, focusing on some other recent constrains in the recent situation of agriculture, where the yield and development in agriculture may be aided by increasing the Mo nutrition.

\section{Introduction}

Molybdenum (Mo) is very important and an essential micronutrient for plants, animals and bacteria [1-3]. A lot of soils in the world suffer due to the deficiency of microelements such as Mo [4,5]. Mo is deficient in more than 44.7 million hectares of land and B is deficient in 33.3 million hectares in China [6]. Consequently, the deficiency of Mo and B of soil is an extensive agricultural problem that induces quality and yield losses in various crop species worldwide $[6,7]$. Mo-deficient plants show poor growth [8] and less contents of chlorophyll and ascorbic acid [9].

It is seen that itself Mo not so much biologically active but mostly occurs as a vital part of a complex organic pterin that is also being called molybdenum co-factor (Moco). Including plants, prokaryotes and animals, Moco being found to binds with molybdoenzyme in the most of the biological systems [10]. A lot of different phenotypes starts to develop when under the insufficiency of molybdenum plant are being grown. Due to the reduction of molybdoenzyme activity maximum of these phenotypes are associated. Enzymes most of them include that are involving in prime $\mathrm{N}$-assimilation like the nitrogenase (nitrogen-fixing enzyme), Nitrate Reductase (NR) and those that are present in legumes nodules bacteroids. In plants together with xanthine dehydrogenase/oxidase some other additional molybdoenzyme also has been recognized that have very important role in the ureide biosynthesis and purine catabolism. It can be seen that in the legumes, during the biosynthesis of ABA the conversion of sulfite to sulfate may be carried by the sulfite oxidase and Aldehyde Oxidase (AO), that is very significant in amino acid metabolism that contains sulfur [10]. Current review articles about the molybdenum in plants, prokaryotes and animals have shown the wide-ranging literature on formation and regulation of Moco and its activity with molybdenum-dependent apoenzymes [10-12]. In the lower order eukaryotes and prokaryotes, the system about the molybdate transport is characterized very well and designed at biochemical, genetics and physiological levels [13]. In the plant development aldehyde oxidase (AO; EC1.2.3.1) that is plant molybdoenzyme, has a very important role in relation to the development of plant and stresses in the environment [1416]. Xanthine dehydrogenase and molybdenum-hydroxylases aldehyde oxidase in plants have distinctive reactive oxygen species signatures that are tempted by the abscisic acid and drought. Biosynthesis of phytohormones is catalyzed by the AO multigene family members in the preceding step, such as ABA and IAA by converting abscisic aldehyde and indoleacetoaldehyde to their respective phytohormones [12]. IAA being the vital member of auxins that are plant hormones has a major crucial role in a lot of activities of plants comprising abscission, root initiation, phototropism, fruit development, gravitropism and apical dominance [12]. The involvement of IAA to stress as in salinity and deficiency of water in plants has also been suggested. In response to environmental stress ABA also plays a very crucial and important role in plants [17].

As molybdenum is vital constitute in the nutrition of plants, this review will inspect the transport of Mo within and into the plants and will also explore the crucial and comprehensive nutrition of Mo in plant growth and development.

\section{Impact of Mo insufficiency on Growth}

Molybdenum insufficiency resembles nitrogen deficiency, as in the plant metabolism the most significant role of Mo is the reduction of nitrate. Plants facing the Mo insufficiency, the leaves start to become pale, restricted in growth, flower development and formation may also be affected and eventually wither. The most typical visual deficiency impact in dicotyledons is the severe abnormality in size. These are caused by the inadequate discrepancy of the vascular bundles at initial development stages of leaf and the necrosis in tissue [18].

There is a direct relationship between the molybdenum bioavailability in the soil and the molybdenum contents in soil. The molybdenum availability will be low if a soil having the lower soil pH [18] and the plant that is facing the Mo less availability shows the lesions and leaves different morphology was $1^{\text {st }}$ time explained by Arnon and Stout, [19] and then in a comprehensive way by Hewitt's group [20].

Mo insufficiency could also be due to a mutation in the Mo-specific uptake system $[21,22]$. In the MOT1, the knockout mutants in mitochondrial transport revealed that there is very minute change in the growth pattern [23]. As is being seen that though, in plant cells there are numerous Mo transporters, 
but a severe phenotype has not been described yet. Finally, when there will be any kind of imperfection of biosynthesis of Moco that can cause molybdenum insufficiency and by this all the activity of Mo-enzyme is highly decreased or can be lost pleiotropically that has severe consequences for the cell. The loss of Mo-enzyme is most drastic for the plant?

1) It has been known that the NR-mutants can destruct the complete NR-activity

2) If as a solitary $\mathrm{N}$ source, with $\mathrm{No}_{3}^{-}$these mutants cultured then loss of NR-activity is lethal [24].

3) There is no observable phenotype if a smash in one of the two mARC proteins occurs.

4) Although somewhat, but it is not intensely altered plant phenotype as the XDH1 loss has no such as lethal consequence.

5) For $\mathrm{AO}$, in $\mathrm{AAO} 3$ only communicated a mutation, so any disorder or loss of $\mathrm{AAO}_{3}$ will ultimately cause a wilty phenotype and it will cause a severe effect on plant growth and development as when abscisic aldehyde converted into $\mathrm{ABA}$, in this $\mathrm{AAO} 3$ has a very crucial and important role $[25,26]$

6) High sulfur dioxide to an atmosphere has not challenged as no phenotype seen provided if there is loss of SO [27].

7) A wilty phenotype can be observed if the absence of $\mathrm{AO}$ activities occurs because basically ABA reduction was observed due to the insufficiency of Moco-sulfarase (АВА3) [28].

So, Moco has very important role in plant growth and development and plant will come toward the death situation if Moco is lost.

\section{Molybdenum in soils}

Mo generally exists in highly soluble form, and is rare in the soils building it liable to leaching. Though, usually consider that in the acidic soils the molybdenum is attached to mineral surface, it may avoid the leaching, but it may also obstruct uptake by microbes. Usually contents of Mo between 0.6 and $3.5 \mathrm{ppm}$ exist in the most of the agricultural soils with about $2.0 \mathrm{ppm}$ an average Mo and $0.2 \mathrm{ppm}$, average available molybdenum. As an oxycomplex $\left(\mathrm{MoO}_{4}^{2-}\right)$, Mo largely occurs in the soil. Because of this, in its behavior in the soil, Mo more resembles to the phosphate or sulfate. By soil minerals and colloids molybdate is adsorbed in related way to these two anions. This adsorption is very closely dependent on the soil $\mathrm{pH}$ [29]. It increases as the $\mathrm{pH}$ falls but at the neutrality it is very low. On acid soil availability of Mo for the plants is the poorest and can be upgraded by foliar application, seed priming, seed coating pelleting and with liming, in case soil is not characteristically lacking in molybdenum [18].

\section{Molybdenum adsorption in soils}

The $\mathrm{pH}$ dependency of Mo adsorption on the soil resembled the one found for clay and oxides minerals. $\mathrm{pH}$ is a very dominant factor in the availability of nutrients [30-32]. It controls many processes occurring in the soil system [33-35]. Absorption demonstrated a peak in the range of $\mathrm{pH} 3-4$, and then declined with the increasing $\mathrm{pH}$ above 4 . With temperature, there is an little increase in the adsorption of Mo on surface of soil [36]. Carroll, et al. [37], to examine the transport of Mo in soil with and without biosolid amendment employed the miscibledisplacement and batch-equilibrium experiments. Sorption of the Mo was revealed to be greater for the biosolid-amended soil. Though, Mo related with biosolid-amended soils is comparatively mobile and bioavailable. Adsorption of Mo was probed in California on 5 arid zone and the results showed that adsorption of molybdenum from $\mathrm{pH}$ 4-8 salinity solution was independent as a function of $\mathrm{pH}$ of solution [37]. By using soil chemical properties Mo adsorption was predicted: iron oxide content, organic carbon content, cation exchange capacity and inorganic carbon content. Generally, in the acidic oxidizing soils, trace metals are readily available and are less available in neutral reducing or alkaline soil )[38,39]. Moreover, not like the other trace metals, with increasing soil $\mathrm{pH}$, there is always increase in availability of Mo in higher plants [40]. In generally, in its anionic form ( $\left.\mathrm{MoO}_{4}{ }^{2-}\right)$ mainly, Mo becomes accessible to plants and soluble in soils having alkaline properties. By contrast, Molybdenum obtainability in acidic soils declines as the adsorption of anion increases to soil oxides $(\mathrm{pH}<5.5)$ [41] Figure 1.

Montmorillonite < nontronite < metahalloysite and illite < kaolinite $<$ kaolinite, the relative adsorption on the clay minerals increased in this order. Goldberg, et al. [43], determined the magnitude of adsorption of Mo following as increasing order: kaolinite < illite < montmorillonite. Though, comparability is difficult about the adsorption affinity per unit surface area or per unit mass, since between adsorbents in different experiments the suspension density varies. They reported that on clay mineral Mo adsorption near the $\mathrm{pH} 3$ was more and then rapidly declined by the increase in $\mathrm{pH}$ up to the adsorption become almost zero near $\mathrm{pH}$ of 7 . The kaolinite point of zero charges of was moved to a high acid $\mathrm{pH}$ value for Mo adsorption on kaolinite, demonstrating mechanism an inner-sphere adsorption for the Mo on such surfaces. Including adsorption at inner or outer-sphere complexes and precipitation, adsorption can occur through a variety of mechanisms.

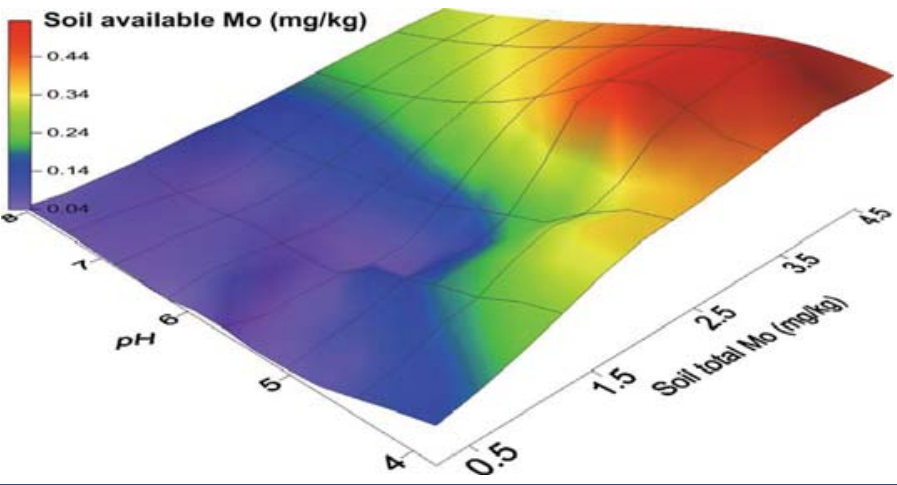

Figure 1: Rational Graphs; soil Mo, pH and available Mo [42].

Citation: Rana MS, Bhantana P, Imran M, Saleem MH, Chengxiao Hu, et al. (2020) Molybdenum potential vital role in plants metabolism for optimizing the growth and development. Ann Environ Sci Toxicol 4(1): 032-044. DOI: https://dx.doi.org/10.17352/aest.000024 
To study the mechanism of Mo adsorption with iron oxides, Lang, et al. [44] used pressure-jump relaxation in order to evaluate the special effects of aging on complex Mo/goethite formed during Mo chemisorptions and to explain Mo/goethite interaction. They concluded that the within suspension Mo transport resulted the slow relaxation, which does not depend on temperature and the fast relaxation represents Mo chemisorptions to the goethite, which decreases with increasing temperature. Understanding the surface speciation in subsurface and surface environment bioavailability is critical to calculating on mineral surfaces. Arai [45] to investigate in-situ Mo surface speciation on goethite applied near edge structure analysis the X-ray absorption. Experimental results showed that with a decline in $\mathrm{pH}$ Mo (VI) coordination environment changes from the tetrahedral to octahedral. The inner-sphere surface species formed by the predominant tetrahedral molecules of Mo (VI), near-neutral $\mathrm{pH}$ however at pH 3-4, comprising octahedrally and tetrahedrally a surface specie mixture are present. In the soil-water environment, Prediction of processes of Mo transport, the surface speciation of $\mathrm{Mo}$ (VI) the $\mathrm{Ph}$ dependent multinuclear may be important.

In sulfidic environments, thiomolybdate species, $\mathrm{MoO}_{\mathrm{x}} \mathrm{S}_{4-\mathrm{x}}$ ${ }^{2-}$, are formed in conditions, anoxic (i.e., DO $<1 \mathrm{mg} \mathrm{l}^{-1}$ ) [46]. This conversion of goethite could be due to the reduction facilitated by the activities of microbial [47]. Impact in the acidic soil is due to the strong adsorption in relation between the $\mathrm{pH}$ and molybdenum that can not be ignored. Some other soil properties may also effect on the availability of Mo. A detail of factors that influence the availability, leaching and adsorption process are shown in Figure 2.

A role of tetrathiomolybdate $\left(\mathrm{MoS}_{4}{ }^{2-}\right)$ in the chemical pathway may be in anoxic sediments, fixation of Mo. Its incorporation was adsorption on or co-precipitation with iron sulfides [48-50]. It forms relatively stable complexes when once $\mathrm{MoS}_{4}{ }_{4}^{2-}$ reacts with pyrite that are engaged as Mo-Fe-S "cubane" structure irreversibly [29,51,52]. Cuboidal Mo-Fe-S clusters are formed by Mo on pyrite that has been shown by $\mathrm{X}$-ray spectroscopy [51]. The adsorption of the $\mathrm{MoO}_{4}{ }^{2-}$ and $\mathrm{MoS}_{4}{ }^{2}$, goethite and pyrite onto these two main iron minerals, has been talked to explain the probable mechanisms of the immobilization of Mo in the anoxic conditions [29], and have concluded that even in the existence of, sulfate, silicates and phosphate, the $\mathrm{MoS}_{4}{ }^{2-}$ may be an eventual pool and may also regulator Mo enhancement in sediments,. The results of the experiment presented that adsorption of $\mathrm{MoO}_{4}{ }_{4}^{2-}$ and $\mathrm{MoS}_{4}{ }^{2-}$ is a sturdy function of surface loading and $\mathrm{pH}$. The retention of molybdate, in $\mu \mathrm{mol} / \mathrm{g}$, with the iron minerals followed the increasing order of the $\mathrm{MoO}_{4}{ }^{2-}$ - pyrite $<\mathrm{MoS}_{4}{ }^{2-}$ - pyrite $<\mathrm{MoO}_{4}{ }^{2-}$ -goethite $<\mathrm{MoS}_{4}{ }^{2-}$-goethite. Helz, et al. [50], recommended that $\mathrm{FeS}$ ion activity products may control the molybdenum concentrations, as well as the $\mathrm{pH}$ in euxinic basins. On the Mo adsorption, some of other anions showed little effect; i.e., selenite adsorption onto $\gamma-\mathrm{Al}_{2} \mathrm{O} 3$ [53,54], arsenate adsorption onto clay minerals [43] and silicate onto goethite and pyrite Figure 3 [29].

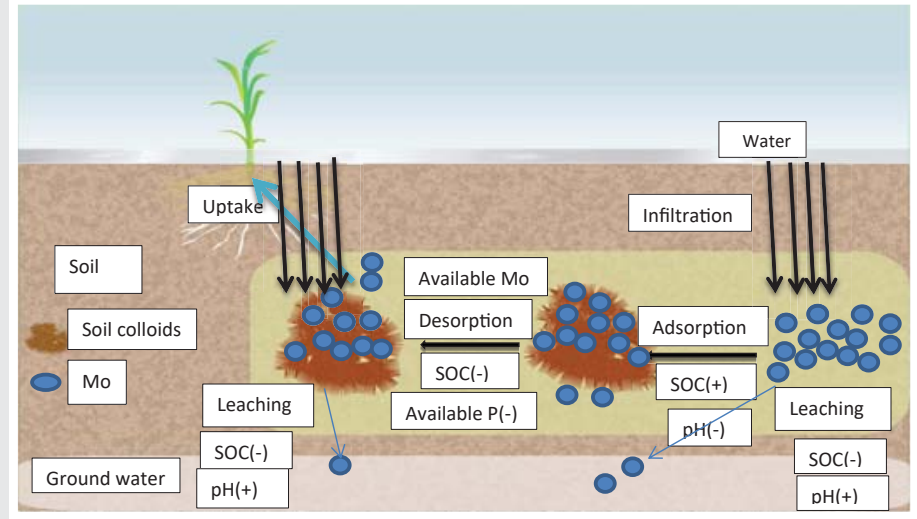

Figure 2: Mo leaching, adsorption and influencing factors.

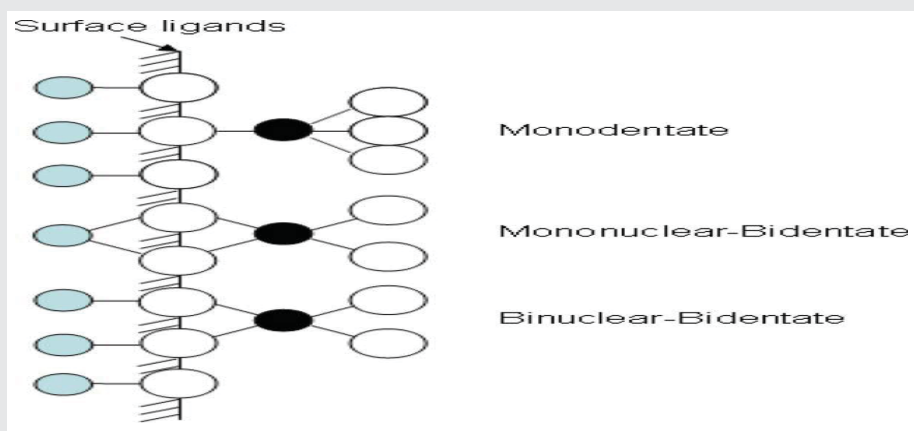

Figure 3: Simplified schematic diagrams of possible molybdate adsorption complexation modes on metal oxides. Legend: () Oxygen, () Molybdenum, () Metal atom (i.e., $\mathrm{Al}$ or $\mathrm{Fe})[126]$.

\section{Oxidation and redox behavior of Mo species}

Molybdenum resembles tungsten and vanadium, in its chemical properties, the Group $5^{\text {th }}$ first number, rather than $\mathrm{Cr}$. Molybdenum, chemically is tremendously versatile, forming compounds in array of the freely interconvertible states of oxidation. Molybdenum shows all the oxidation states from 2 - to 6+ in its compounds, among which the lowest oxidation states, ranges from $2^{-}-1^{+}$, found in the complexes with the ligands acceptor, primarily cyclopentadiene, C-monoxide and related compounds, $\mathrm{P}$, nitric oxide and $\mathrm{Ar}$-donor ligands. Molybdenum the short oxidation states (2- to 2+) are unlikely be to arise in enzymatic processes or encountered in biological systems. In its oxidation states the Mo in its oxidation $3+$ to $6+$ forms the majority of complexes with S-, O-, halogens and $\mathrm{N}$-donor ligands. Mo (IV) can also be stabilized by $\mathrm{S}$ in which the most stable sulfide is disulfide and in complex ion $[\mathrm{Mo}(\mathrm{CN})$ $8]^{4-}$, Mo (IV) is powerfully stabilized by cyanide. By the oxo molybdenum species, $\mathrm{Mo}(\mathrm{V})$ and $\mathrm{Mo}(\mathrm{VI})$ in oxidation states are dominated. Bard, et al. [55], have reported that molybdates are less powerful oxidants in acidic solutions than chromates and vanadates where the oxidation potential decreases with the increasing $\mathrm{pH}$. These species of molybdenum are coordinated with hydroxide, oxygen, sulfate, water and chloride, with respect to their oxidation and the reduction [56]. However, lower oxidation states of Mo than $3+$ and $4+$ are not obtained by reduction, while in alkaline and neutral solutions by dithionite molybdates (Mo VI) may be reduced to molybdenum(V) and oxo molybdenum(IV) complexes, except that weak reducing agents, including, sulfide and hydrogen make Mo blue. 
Mo chemistry in the soils is very complex because the Mo oxidation state differs from II to VI. Molybdenum concentrations within the soil profile and species vary depending on the nature of the soil adsorptive complexation and with the chemical characteristics of soil solution [57]. Under anoxic conditions Mo is predicted to be in the IV oxidation state [58]. Predominantly $\mathrm{Mo}$ is found as $\mathrm{Mo}(\mathrm{Vl})$ oxyanions $\left(\mathrm{MoO}_{4}{ }^{2-}\right)$ with a pH of 4-8 in oxic soils. The chemistry of Mo in soils is further complicated by the complexation of Mo with metals (e.g., $\mathrm{CaMoO}_{4}{ }^{\circ}, \mathrm{MgMoO}_{4}{ }^{\circ}$ ) [59]. In natural water Molybdenum forms molybdate $\mathrm{Mo}(\mathrm{VI})$ oxyanions. Mo(VI) anions' adsorption in acidic soils and sediment typically control the fate and transport of $\mathrm{Mo}(\mathrm{VI})$ anions in the natural environment of water-soils-sediments.

\section{Plants, enzymes need Mo and Mo cofactor}

In order to have biological activity, Mo is complexed with pterin compound thus making the prosthetic group named Moco, [15,60,61]. As anion $\mathrm{MoO}_{4}{ }^{2-}, \mathrm{Mo}$ is abundant in oceans. Moreover, molybdate ion is the form that is only available for bacteria and plants in soil. If the plant takes too much high Mo, it may have toxic effects on it [62]. On the opposite side its insufficiency is lethal for the plant. Only a handful of Molybdenum-enzymes were found among eukaryotes while, most they are of bacterial origin.

To scavenge Mo in the existence of competing anions molybdenum needs specific systems oof uptake. Mainly, transport follows from up to down to the stem and roots signifying when molybdate applied solely to leaves, that the molybdate is very mobile translocated among numerous tissues of the plant. Moreover, the result displays that an effective inhibitor of molybdate uptake is sulfate pioneered speculations on the nature of molybdate transporters [63].

Table 1. In higher plants components of molybdenum metabolism (Arabidopsis thaliana). In fact, molybdate and sulfate as they are alike in size, have a high grade of resemblance, both possess the structures tetrahedral and the double negative charge $\left(\mathrm{MoO}_{4}{ }^{2-}, \mathrm{SO}_{4}{ }^{2-},\right)$. Biosynthesis of Moco is the only process known to need molybdenum straight by plants that is finalized in the cytosol and initiated in the mitochondria [16,64]. Only little knowledge is present about the enzymatic regulation and genetics of Moco biosynthesis in the plants, even though the biosynthesis of Moco is well understood. The information that is existing only in this reverence concerns in the Arabidopsis MOT1 mutant, molybdenum metabolism-related genes expression that was developed to induce the deficiency of molybdate endogenous by the supply additional molybdate was grown without it. [65]. In fact, under molybdate deficiency, the genes CNX2 and CNX6 Moco biosynthesis were revealed to be the up-regulated, which was similarly true for the Moco sulfurase ABA3, the molybdo enzymes NR2 and NR1, and transporter MOT2.Molybdenum cofactor (Moco). In plants Mo-enzymes to this end known are five in number.: mitochondrial amidoxime reductase (mARC), xanthine dehydrogenase (XDH), N-reductase (NR), $\mathrm{S}$-oxidase (SO) and aldehyde oxidase (AO). There is another type of Mo-containing cofactor, in addition to the pterin type

of the cofactor, another type of cofactor having Mo, calling in bacterial nitrogenase which is found only once in nature, developing the cofactor iron-molybdenum, FeMoco. Biological nitrogen fixation in the biosphere is a vital step in the cycle of $\mathrm{N}$, nitrogenase is required for Biological nitrogen fixation. All other containing Mo, considered to this end have the pterintype cofactor Table $2[66]$.

Generally, the transmission of an oxygen atom to is catalyzed by all the Mo-enzyme or to from a substrate (Hille, 2002). Each reaction, by transfer of two electrons either oxidation or reduction, is also characterized by this, which

Table 1: In higher plants components of molybdenum metabolism (Arabidopsis thaliana).

\begin{tabular}{|c|c|c|}
\hline Protein names & Agi code & Known / proposed function \\
\hline $\begin{array}{l}\text { MOT1/SULTR } \\
5 ; 2\end{array}$ & AT2G25680 & Molybdate transport \\
\hline $\begin{array}{l}\text { MOT2/ } \\
\text { SULTR5; } 1\end{array}$ & AT1G80310 & Molybdate transport/export from the vacuole \\
\hline CNX1 & AT5G20990 & Moco biosynthesis step 3 \\
\hline CNX2 & AT2G31955 & Moco biosynthesis step 1 \\
\hline CNX3 & AT1G01290 & Moco biosynthesis step 1 \\
\hline CNX5 & AT5G55130 & Moco biosynthesis step 2 \\
\hline CNX6 & AT2G43760 & Moco biosynthesis step 2 \\
\hline CNX7 & AT4G10100 & Moco biosynthesis step 2 \\
\hline Nia1/NR1 & AT1G77760 & Nitrate reductase (Minor form) \\
\hline $\mathrm{Nia} 2 / \mathrm{NR} 2$ & AT1G37130 & Nitrate reductase (Main form) \\
\hline so & AT3G01910 & Oxidation/elimination of cytotoxic sulfite \\
\hline $\begin{array}{l}\text { mARC1/ } \\
\text { MOSC1 }\end{array}$ & AT4G44720 & Unknown \\
\hline $\begin{array}{l}\text { mARC2/ } \\
\text { MOSC2 }\end{array}$ & AT1G30910 & Unknown \\
\hline AA01 & AT5G20960 & Unknown \\
\hline $\mathrm{AAO} 2$ & AT3G43600 & Unknown \\
\hline AAO3 & AT2G27150 & ABA biosynthesis \\
\hline $\mathrm{AAO} 4$ & AT1G04580 & Synthesis of benzoic acid \\
\hline AtXDH1 & AT4G34890 & Purine degradation \\
\hline AtXDH2 & AT4G34900 & Unknown \\
\hline ABA3/LOS5 & AT1GI6540 & $\begin{array}{l}\text { Mocosulfuration and activation of } \mathrm{AO} \text { and } \mathrm{XDH} \\
\text { proteins }\end{array}$ \\
\hline ATM3/ABCB25 & AT5G58270 & $\begin{array}{l}\text { Transporter involved in cytosolic Fe-S assembly } \\
\text { and Moco synthesis }\end{array}$ \\
\hline
\end{tabular}

Table 2: Mo enzyme in the plant (Arabidopsis thaliana), subcellular location and their function.

\begin{tabular}{|c|c|c|c|c|}
\hline Mo enzyme & $\begin{array}{c}\text { Number of } \\
\text { genes }\end{array}$ & $\begin{array}{c}\text { Subcellular } \\
\text { location }\end{array}$ & Function & $\begin{array}{c}\text { ROS/RNS } \\
\text { side product }\end{array}$ \\
\hline Nitrate reductase & 2 & Cytosol & Nitrate assimilation & $\mathrm{NO}$ \\
\hline Sulfite oxidase & 1 & Peroxisome & $\begin{array}{c}\text { Sulfite } \\
\text { detoxification }\end{array}$ & $\mathrm{H}_{2} \mathrm{O}_{2}$ \\
\hline $\begin{array}{c}\text { Xanthine } \\
\text { dehydrogenase }\end{array}$ & 2 & Cytosol & $\begin{array}{c}\text { Purine degradation, } \\
\text { NADH oxidase }\end{array}$ & $\begin{array}{c}\text { Superoxide } \\
\text { anions }\end{array}$ \\
\hline Aldehyde oxidase & 4 & Cytosol & $\begin{array}{r}\text { Synthesis of ABA } \\
\text { (Auxins) }\end{array}$ & $\begin{array}{c}\mathrm{H}_{2} \mathrm{O}_{2} \\
\text { Superoxide } \\
\text { anions }\end{array}$ \\
\hline $\begin{array}{c}\text { Mitochondrial } \\
\text { amidoxime } \\
\text { reductase }\end{array}$ & 2 & Mitochondria & Detoxification (?) & n.d \\
\hline
\end{tabular}

Citation: Rana MS, Bhantana P, Imran M, Saleem MH, Chengxiao Hu, et al. (2020) Molybdenum potential vital role in plants metabolism for optimizing the growth and development. Ann Environ Sci Toxicol 4(1): 032-044. DOI: https://dx.doi.org/10.17352/aest.000024 
imposes to fluctuate between IV and VI, its oxidation state of Mo atom. Mo-enzymes are the homodimeric proteins that are present in eukaryotes which are functioning solitary as a dimer, but not as monomer. On the monomer of enzyme isolated domain are identified that are bound to it, different prosthetic groups are involved by some harbor an electron transport chain. Figure 4, point out the five Mo-enzymes of plants domain structure where by the regions that are very much capricious in the order, the domains are linked as a result clearly serving as inter-domain joint regions. It is evident that Mo-enzymes into two classes can be subdivided: XO oxidase family is symbolized by $\mathrm{AO}$, and XDH while Mo-enzyme's SO-class is formed by the NR and SO both classes sharing the domains. From GTP to CPMP the conversion starting, in mitochondria basic steps of Moco biosynthesis are shown, entirely in cytosol succeeding steps continue. Moco-binding proteins (MoBP) and Moco biosynthesis enzymes (named Cnx) have been represented in blue. By $\mathrm{Cnx} 5$, consisting of $\mathrm{Cnx} 6$ and Cnx7 MPT-synthase is sulfurated, with sulfur donor that is primary $(\mathrm{X}-\mathrm{S})$ militarized by $\mathrm{Cnx} 5$ ( $\mathrm{RLD}$ ) rhodanese-like domain being unidentified. For adenylation and activation of the small MPT synthase subunit $\mathrm{Cnx7}$, the adenylation domain of the $\mathrm{Cnx} 5(\mathrm{AD})$ is required. It is supposed that after dithiolene formation, copper $(\mathrm{Cu})$ is inserted directly. Moco can be either bound to these Mo-enzymes $\mathrm{NR}, \mathrm{SO}, \mathrm{XDH}, \mathrm{mARC}$ and $\mathrm{AO}$, to a MoBP (Moco-binding protein), or to the MBD (Mocobinding C-terminal domain) of Mocosulfurase ABA3. ABA3 $\mathrm{C}$-terminus is sulfuration platform for Moco. $\mathrm{ABA} 3$ domain like NifS makes the persulfide protein-bound, which bound to its C-terminus is transferred to the Moco that for the sulfurated, Moco exchanges the non-sulfurated. In the figure, Mo-enzyme monomers domain structure is given. It is obvious that Moenzymes of eukaryotes are interrelated to each other: A pair is formed by the $\mathrm{AO}$ and $\mathrm{XDH}$, from $\mathrm{ABA} 3-\mathrm{MBD}$, mARC arose and forms NR a pair with SO Figure 5 [16].

\section{Mo crucial role in biological nitrogen fixation}

Specifically for plants, Mo is a micronutrient that with nitrogen-fixing bacteria form root nodules, however trace amounts of Mo are also used in a protein involved with

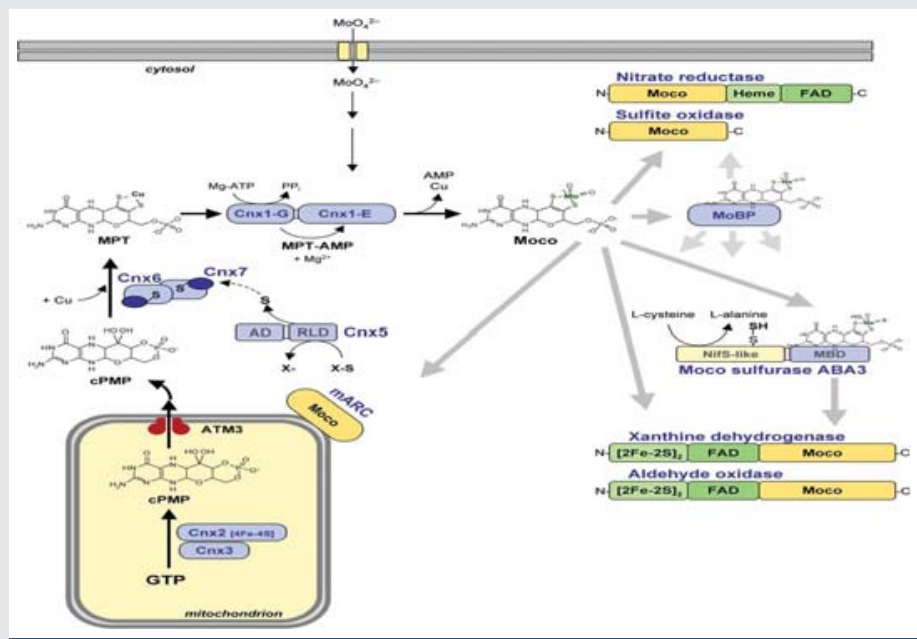

Figure 4: In plants biosynthesis, maturation and distribution of Moco [16].

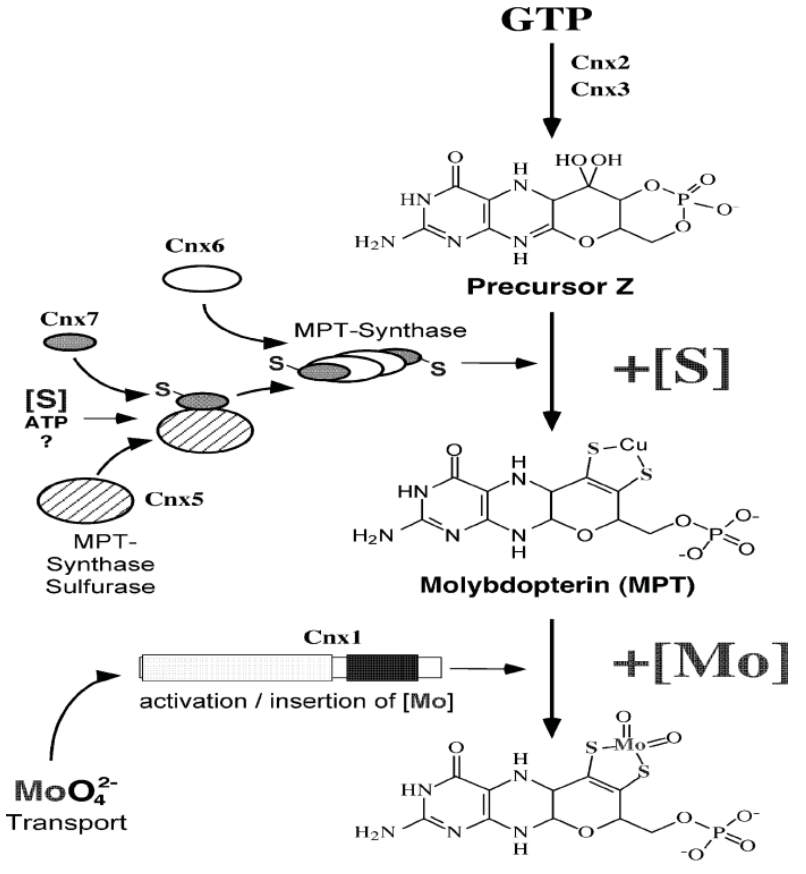

Molybdenum Cofactor

Figure 5: Formation of molybdoprotein and insertion of sulfur, conversion of GTP to precursor $Z$, the formation of Moco and insertion of molybdenum. According to the Cnx nomenclature the protein involved is named.

nitrogen metabolism and uptake plants that do not form nodules [67]. Its significance to the $\mathrm{N}_{2}$ fixation is vibrant, given that Mo in 'FeMoCo' cofactor is at heart of the nitrogen reduction process - at least for the most of the nitrogenases. Two atoms of molybdenum contained by the Mo-Fe protein and has two distinct types of oxidation-reduction centers: four Fe-S centers and two iron-molybdenum cofactors called FeMoco. The active site of Mo-containing nitrogenase protein constitutes by the FeMoco of the nitrogenase in the $\mathrm{N}_{2}$-fixing organisms [68]. Although at low supply, into the nodules molybdenum is preferentially transported. [69], molybdenum deficiency-induced nitrogen deficiency is widespread in legumes depend on $\mathrm{N}_{2}$ fixation, predominantly in acid mineral soils of the subhumid and humid tropics. It is also described that an impaired nitrogen fixation activity showed by $B$. japonicum strain deficient in Mo transport when inoculated to the soybean roots. More dramatic signs of deficiency in laboratory conditions showed by the several different legumes that were sternly starved of Mo [70,71]. There are reports that in the field conditions foliar applications of the molybdenum to grain legumes increase the levels of nodule mass and $\mathrm{N}_{2}$ fixation, consequentially in higher seed yield and N Figure 6 $[72,73]$.

Soybean growing without Mo fertilizer on a Mo-deficient soil in the upper left. Soybeans were a normal green color, indicating adequate $\mathrm{N}$. Soybean without Mo but with $\mathrm{N}$ fertilizer as shown in the upper right. Soybean growing without $\mathrm{N}$ in the lower-left fig. and with Mo caused in superior growth and effectively nodulated soybean plants while nodulated soybean roots from plants growing on Mofertilized soil in the lower right [74]. 

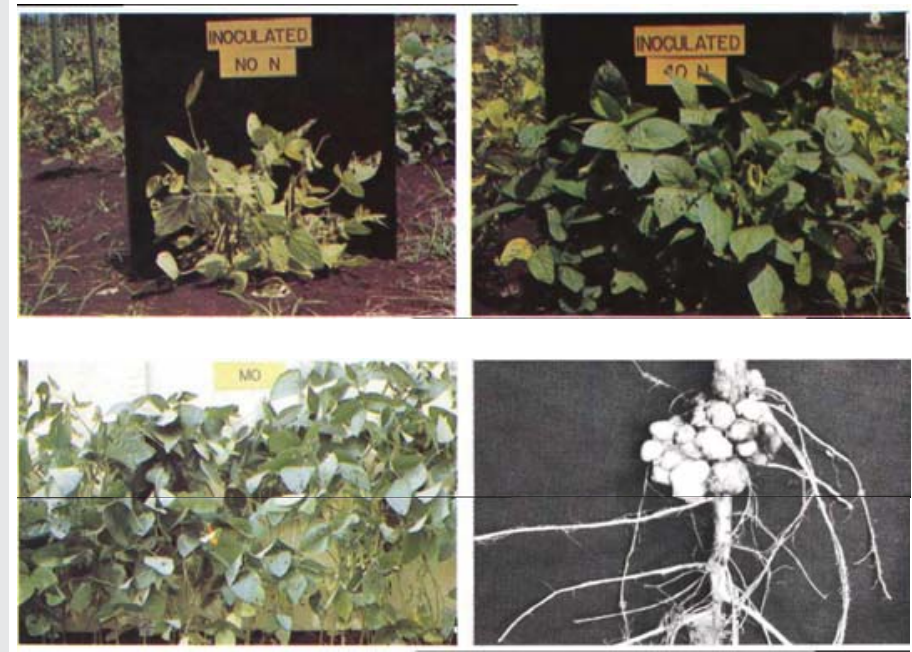

Figure 6: Note the apparent N-deficiency symptoms exhibited by the leaves. Soybean growing without Mo fertilizer on a Mo-deficient soil in the upper left. Soybeans were a normal green color, indicating adequate N. Soybean without Mo but with $\mathrm{N}$ fertilizer as shown in the upper right. Soybean growing without $\mathrm{N}$ in the lower-left fig. and with Mo caused in superior growth and effectively nodulated soybean plants while nodulated soybean roots from plants growing on Mofertilized soil in the lower right [74]

\section{Molybdenum uptake, storage and transport into the cells}

By the sulfate transporters or related systems, it is being proposed that molybdate distribution and import are facilitated [75]. In contrast to the homeostasis of bacterial molybdate, the transport of Mo in eukaryotes is less understood. Protein MOT1that belongs to the family that is large sulfate carrier and that was revealed to transport molybdate by the ultrahigh affinity across the cellular membranes [23,76,77]. In the plasma membrane surprisingly, it was not found to reside. Conflicting reports localized it to the mitochondrial envelope or to endomembrane system [23,77]. As in the cytosol, into the Moco-backbone the insertion of Mo occurs both suggested the subcellular locations are questionable. Another molybdate transporter of sulfate transporter family, in addition to MOT1, it is being described the vacuole provide functional evidence for MOT2 that is confined to the tonoplast and as an important molybdate store $[21,22]$, and low content of Mo in the leaves while in seed by the accumulation of Mo contents, the plants that are deficient in MOT2 are characterized. Still for Mo cellular importer is missing, but it is being expected that this task is carried not only in animals but also in autotrophs by the additional transporters. It can be assumed, in addition to a high-affinity system, non-specifically molybdate can also move in the cell by sulfate uptake system that has been revealed for a sulfate transporter [78-80].

In the wildtype and MOT2 mutant leaves, however, it is found total molybdenum contents with the levels of Moco were to correlate, which indicates molybdate at cellular levels, Moco synthesis is adjusted by the plant.

\section{Molybdenum efficacy enhancement techniques}

Seed coating, treatment and pelleting with Molybdenum: Numerous studies have shown the efficacy of the Mo seed coating $[81,82]$. Seeds were treated by the Mo ( $80 \mathrm{~g} / \mathrm{ha})$ causing

in improved comparative grain yield, chlorophyll index, seed weight and pod number. It shows the better results when soybean seeds with ferrous sulfate $500 \mathrm{mg} / \mathrm{kg}$ and ammonium molybdate $250 \mathrm{mg} / \mathrm{kg}$ were pelleted were highly effective for the improvement of dry matter production, yield, plant height, growth rate and area index of leaves $[81,82]$. Similarly in field experiments, to increase yield of soybean and cowpea on acidic soils, benefits from the Mo applied together with the rock phosphate or alone, were greater or comparable than liming evaluating the effectiveness of a number of pelleting materials [83]. Though, from Mo seed-coating, several reports indicating no toxicity or improvement. Burton and Curley [84] reported that bacterial survival, $\mathrm{N}$ fixation and nodulation were strappingly suppressed when seed with sodium molybdate was pelleted. By inoculant and Mo nearly inoculated bacteria 99\% died just after seed treatment in four days. As groundnuts kernel yield is increased due to seed dressing nearly more than $300 \mathrm{~kg} \mathrm{ha}^{-1}$ in Senegal by applying $28 \mathrm{~g}$ ammonium molybdate/ ha ([85]. In Sierra Leone on groundnuts grown on an upland soil seed pelleting with $0.2,0.4$ and $0.8 \mathrm{~g}$ inoculation with rhizobia plus sodium molybdate/100 g seed was tested. Where sodium molybdate was applied at $0.2 \mathrm{~g} / 100 \mathrm{~g}$ was applied to seeds, by this it is seen an increased protein content by $4.21 \%$, DM yield by $17.2 \%, 14.0 \%$ grain yield and $\mathrm{N}$ uptake $38.5 \%$ [86]. Rhodes and Nangju [83] led field trials in increasing yields of cowpea and soya bean to estimate the efficiency of the numerous pelleting materials on an acid soil in the Sierra Leone. Mo increased yield and the growth of the cowpeas when it is applied combined with the rock phosphate or either alone, but on soya bean it had no significant effect on the yield and growth, even though per plant number of nodules increased significantly. It is reported by the Rhodes and Kpaka [87], by application of Mo, it boosted dry matter, seed yield and pod weight of cowpeas. At rate of $0.4 \mathrm{~g} / 100 \mathrm{~g}$ seed treatment, yield increased by pelleting seed with nitro-molybdenum by $21 \%$, over control or $1.39 \mathrm{t} \mathrm{ha}^{-1}$ (Table 3). Applying Mo by this method may show attraction to the small landholding farmers as it is cheap, simple, is less subject to the vagaries of wind and rain and does not require any spraying equipment.

Some other researchers also observed on bradyrhizobium, salts suppressive effects used as molybdenum sources [88,89]. But there is also reports present that indicates in improving crop performance Mo seed coating is effective, from the bacterial strains used for inoculation, it may have toxic effects. So, before using Mo seed coating, it must be evaluated the seed coating efficacy of Mo with bacterial strains.

Table 3: Effects of Mo on cowpea performance [86].

\begin{tabular}{|c|c|c|c|c|}
\hline Teatment & $\begin{array}{c}\text { Dry matter (g/ } \\
\text { plant) }\end{array}$ & $\begin{array}{c}\text { Nodule } \\
\text { weight } \\
\text { (mg/plant) }\end{array}$ & $\begin{array}{c}\text { Pod weight weight } \\
\text { (t/ha) }\end{array}$ & Seed yield (t/ha) \\
\hline No Mo & $10.47 \mathrm{a}$ & $144.0 \mathrm{a}$ & $1.445 \mathrm{a}$ & $1.15 \mathrm{a}$ \\
\hline $\begin{array}{c}\text { Mo } \\
\text { sprayed }\end{array}$ & $13.09 \mathrm{~b}$ & $146.3 \mathrm{~b}$ & $1.519 \mathrm{a}$ & $1.15 \mathrm{a}$ \\
$\begin{array}{c}\text { Mo } \\
\text { pelleted }\end{array}$ & $13.56 \mathrm{~b}$ & $179.0 \mathrm{a}$ & $1.892 \mathrm{~b}$ & $1.39 \mathrm{~b}$ \\
\hline LSD (0.05) & 2.08 & 49.3 & 0.22 & 0.18 \\
\hline
\end{tabular}

Citation: Rana MS, Bhantana P, Imran M, Saleem MH, Chengxiao Hu, et al. (2020) Molybdenum potential vital role in plants metabolism for optimizing the growth and development. Ann Environ Sci Toxicol 4(1): 032-044. DOI: https://dx.doi.org/10.17352/aest.000024 


\section{Seed priming with molybdate}

Numerous studies pointed out that for Mo application, seed treatment is a more effective method than soil application. For instance, in eastern India 48 trials conducted, mean yield was increased by $17 \%-22 \%$ by application of Mo as compared to the control where Mo was not applied and when it is applied to soil the increase was $20 \%-25 \%$ ( $[90,91]$. Similarly, over the no application control, Mo through the seed treatment $(4 \mathrm{~g}$ kg-1 seed) application was more economical and effective for increasing the yield by $15.79 \% ; 10.53 \%$ with $1.5 \mathrm{~kg} / \mathrm{ha}$ the soil application [92]. 0.1 or $1 \%$ sodium molybdate solution, priming of Trifolium subterraneum L. (Subterranean clover) seeds in improving yield and growth was as alike effective as through the soil application, in soil that is deficient in Mo. Donald and Spencer [90] reported that in grains high $\mathrm{N}$ and Mo content resulted in the seed priming than soil application as the application levels increases for the maximum yield. Mohandas [93] reported that improved nitrogen fixation, dry matter accumulation, yield and nodulation was seen when common bean seeds primed in sodium molybdate. It has been reported that a yield increase of compared with Mo soil application $27 \%$ by seed priming in a pot study on chickpea, with Mo for $8 \mathrm{~h}$ at $0.5 \mathrm{~g} / \mathrm{L}$ solution of sodium molybdite, while in the field experiment, increase in the yield of chickpea from the same treatment was $20 \%[94,95]$. In Bangladesh, over untreated control yield an increase was $37 \%-90 \%$ and was up to $50 \%$ more than the water-soaked control in trials at farmers' fields at different locations [96]. By adding rhizobium in the priming solution, the efficacy with Mo seed priming could be enhanced. Similarly, in Vigna radiata L. (Green gram), priming with the rhizobia and sodium molybdate ominously enhance the nutrient uptake, nodulation, crop yield, nitrogen fixation and growth of the plant. In fulfilling the Mo requirements of various crops, the Mo application by the priming of seed is highly economical and more effective as compared to the soil application, however with rhizobia its amalgamation needs to be the more investigated and modified. Pattanayak, et al. [97], indicated that fertilizer application efficiency is also increased by combining the seed treatments that indicate the better use of the resources. Even though in the priming media incorporation of rhizobial strains was synergistic, the protocol should be modified for micronutrient requirements and individual crops Table 4 .

\section{Foliar application}

Katyal and Randhawa [99] indicated that a spray solution may be comprised of $0.1 \%-0.3 \%$ of soluble Mo. With the increasing soil $\mathrm{pH}$, the Mo availability increases, and acid soils that have a $\mathrm{pH}<5.2$, Mo available amount to plants is very low, i.e., $0.10 \mathrm{mg} / \mathrm{kg}-0.25 \mathrm{mg} / \mathrm{kg}$ [18]. Since in the phloem and xylem Mo is highly mobile, and this Mo by seed treatment can be provided or may be by the foliar application as the crops require it in low amounts. Foliar sprays of Mo are more effective often than the applications to soils, principally for the acidic soils, and if it is applied at early stages of plant development it may be of supreme effectiveness [100]. Foliar spray effectiveness depends on nutrient its translocation into the plant and uptake rate by the leaves [101]. Mo applied by leaf spray, the leaves rapidly absorb it. Campo and Hungria [102] found that to the soybean nodules translocation of the Mo was very rapid, and after application of five days reported the highest concentration of molybdenum in nodules.

On enhancing plant yield the effect of Mo fertilization is often related to an improved capability of the plant to consume nitrogen. Biscaro, et al. [103] confirmed that grain yield of common bean enhances when there is the Mo and $\mathrm{N}$ combined leaf supply. By plants Mo status the activities of nitrate reductase and nitrogenase are affected, and in the plants that are suffering from the deficiency of Mo their activities are often suppressed [104]. After 25 days plant emergence Mo application through the foliar application $\left(40 \mathrm{~g} / \mathrm{ha}^{-1}\right)$ greatly improved the NR and activities of nitrogenase that results in increase in total nitrogen accumulated in the shoots of common bean [73]. calengo, et al. [105] reported that in common bean deficiency of Mo results in low efficiency of $\mathrm{N}$ assimilation of plants.

Lombin, et al. (1985) [106] considered the effect of molybdenum i.e,30 g ammonium molybdate/ha, in 1971, 1972 wet and dry year respectively, sprayed on groundnut three weeks after sowing at the Samaru, northern Nigeria Table 5.

It has been found that Mo in the dry year is more likely to increase kernel yields of the groundnut short-season varieties. The groundnuts kernel yield by $200 \mathrm{~kg} \mathrm{ha}^{-1}$ increased by the foliar application of Mo [107]. After 10 days emergence10o

Table 4: Effect of molybdenum seed treatment in different crops on yield of grain and grain enrichment.

\begin{tabular}{|c|c|c|c|c|c|c|c|}
\hline Source & App. mode & App. rate & Crop & $\begin{array}{c}\text { Increase in grain yield } \\
\text { over untreated control } \\
(\%)\end{array}$ & $\begin{array}{l}\text { Increase in nodule number } \\
\text { over untreated control (\%) }\end{array}$ & $\begin{array}{c}\text { Increase in grain mineral } \\
\text { content over untreated } \\
\text { control }(\%)\end{array}$ & Reference \\
\hline Sodium molybdate & $\begin{array}{c}\text { Seed } \\
\text { treatment }\end{array}$ & $\begin{array}{c}0.2 \mathrm{~g} / 100 \mathrm{~g} \\
\text { seed }\end{array}$ & Groundnut & 14 & & & Haque and Amara [86] \\
\hline Sodium molybdate & $\begin{array}{c}\text { Seed } \\
\text { treatment }\end{array}$ & $\begin{array}{c}0.4 \mathrm{~g} / 100 \mathrm{~g} \\
\text { seed }\end{array}$ & Soyan bean & 154 & & & Haque and Bundu [98] \\
\hline Nitro-molybdenum & $\begin{array}{c}\text { Seed } \\
\text { treatment }\end{array}$ & $\begin{array}{c}0.4 \mathrm{~g} / 100 \mathrm{~g} \\
\text { seed }\end{array}$ & Cowpea & 21 & & & Rhodes and Kpaka [87] \\
\hline Sodium molybdate & Seed soaking & $1 \mathrm{mg} \mathrm{L}^{-1}, 1 \mathrm{~h}$ & Common bean & 12.66 & 122.73 & - & Mohandas [93] \\
\hline Sodium molybdate & Seed soaking & $2 \mathrm{mg} \mathrm{L}^{-1}, 1 \mathrm{~h}$ & Common bean & 53.68 & 272.73 & - & Mohandas [93] \\
\hline Sodium molybdate & Seed soaking & $5 \mathrm{mg} \mathrm{L}^{-1}, 1 \mathrm{~h}$ & Common bean & 11.61 & 90.91 & - & Mohandas [93] \\
\hline Sodium molybdate & Seed priming & $0.0026 \mathrm{M}, 8 \mathrm{~h}$ & Chickpea & & - & 7400 & Johnson, et al. [122] \\
\hline \multirow[t]{2}{*}{ Sodium molybdate } & Seed priming & $0.0026 \mathrm{M}, 12 \mathrm{~h}$ & Lentil & & - & 0 & Johnson, et al. [122] \\
\hline & & & & & & & 039 \\
\hline
\end{tabular}

Citation: Rana MS, Bhantana P, Imran M, Saleem MH, Chengxiao Hu, et al. (2020) Molybdenum potential vital role in plants metabolism for optimizing the growth and development. Ann Environ Sci Toxicol 4(1): 032-044. DOI: https://dx.doi.org/10.17352/aest.000024 
Table 5: Effect of Mo application on groundnut yield.

\begin{tabular}{|c|c|c|c|c|c|}
\multirow{2}{*}{ Year } & \multirow{2}{*}{ Variety } & \multirow{2}{*}{ Plant part } & \multicolumn{3}{|c|}{ Pod yield(Kg/ha } \\
\cline { 4 - 6 } & & No Mo & With Mo & Difference \\
\hline \multirow{2}{*}{1971} & \multirow{2}{*}{ S.61 } & Kernel & 1718 & 1894 & +176 \\
\hline \multirow{2}{*}{1972} & \multirow{2}{*}{ S.61 } & Haulm & 2078 & 2892 & +814 \\
\hline \multirow{2}{*}{1972} & Spanish 205 & Kaulm & 2992 & 3633 & +123 \\
\hline & MK 374 & Kernel & 1893 & 2298 & +405 \\
\hline
\end{tabular}

g sodium molybdate/ha foliar sprays applied to maize that eliminated the Mo-deficiency symptoms in Zimbabwe. Though, when the spray was applied at the same rate after 4 weeks of emergence, that proved ineffective. While it has been seen that on maize crop when we use the foliar application at $100 \mathrm{~g} /$ ha sodium molybdate after 10 days of emergence, it was seen that was adequate to raise Mo content in seed above $(0.08 \mathrm{ppm}$ Mo) critical concentration [108]. In leaf tissue of sunflower, the increase of $\mathrm{N}$ and $\mathrm{NH}_{4}{ }_{4}^{+}$and concentration with Mo rates shows that $\mathrm{N}$ assimilation improved by this Mo that is, reduction of $\mathrm{NO}_{3}{ }^{-}$to $\mathrm{NH}_{4}{ }^{+}$and consequently transformed in proteins, other compounds that are organic and amino acids in plants. Firstly all the nitrogen should be reduced to $\mathrm{NH}_{4}{ }^{+}$when it is taken up by plant, because for assimilation into the $\mathrm{N}$ carrying amino acids, the only reduced nitrogen form that is available to plants $[109,110]$.

\section{Soil application}

There are many crops, that need Mo fertilizers [111]. High nitrogen application and under the low $\mathrm{pH}$ conditions with the Mo, oilseed rape should be fertilized. The Mo uptake by oilseed rape can also be decreased by the sulfur application [112]. Usually, 70-200 $\mathrm{g} \mathrm{Mo} \mathrm{ha}^{-1}$ for the forage legumes is adequate and for the other field crops. In soil in absence of molybdenum, the plant molybdoenzymes can be broken down and brutally obstruct the nitrogen fixation by the soil bacteria [22].

Up to $400 \mathrm{~g} / \mathrm{ha}$ cauliflower may need molybdenum but among the crops and soils, optimum dose for Mo varies. Katyal and Randhawa,1983 reported that cauliflower may need Mo application every year but one application on fodder and pasture plants may create for several years, residual effects. For about 1 to 15 years residual effects may last in Australia and New Zealand, where arable crops and pasture are receiving with super-phosphate molybdenum-enriched giving Mo 20-60 g/ ha, [113]. Parish, et al. [114] indicated the significantly improved sugar-cane growth were to a low humic Latosol Mo applied in Mauritius. In the West African semi-arid zone Molybdenum applications on sandy aeolian soils had positive effects on $\mathrm{N}$ fixation, growth, seed yield, nodulation of groundnuts [85]. A positive response toward the growth of cowpea with Mo in an experiment was seen on acidic Shante soil at Ogbomosho, which was typical of soils that are sandy in nature in the transition zone of the Nigerian forest/ savanna and at Ibadan on Adio soil. Mo application at the rate of $0.05 \mathrm{ppm}$ shows the more efficient response, with up to $4 \mathrm{ppm}$ Mo smaller responses occurring at this application rates. To the Mo deficiency in acid soils maize appears to be relatively susceptible.
On very acidic soils in Australia, some research conceded out that indicated that when fertilization of Mo applied it was possible to attain higher yields of wheat.In the seed material the actual Mo concentration shows the increment in yield. Better the yield; lower the Mo content in seeds, stimulating Mo fertilization effects [111]. Mo rates between 35 and $140 \mathrm{~g} / \mathrm{ha}$ had a noteworthy effect. Towards seed molybdenum increasing concentration in common bean has been examined by applying the Mo rates at high level, between 90 and $720 \mathrm{~g} / \mathrm{ha}$, applied to leaves [115].

In Zimbabwe greenhouse experiments indicated on a clayloam red soil Mo deficiency as a major growth-limiting factor. Field experiments show that when we apply Mo in the maize, then early growth of maize increased on the soils having a $\mathrm{pH}$ between 4.4 and 4.8 [116-127].

\section{Conclusion}

Our considerate of the function and the biological role of the molybdenum is progressing rapidly. Moco as it occurs in CNX mutants the complete loss of it is lethal and when they are grown in the soil leads to the death of plants. However in the cell culture, when grown on the media these mutants could be retained alive with the reduced $\mathrm{N}$ as $\mathrm{N}$-source. As well as Moco biosynthesis proteins the crystallization of further molybdenum enzymes is under way. Though Moco on ABA levels have an important effect in the plant cells, Moco is also uniquely takes part in ABA synthesis and as a result a role in transpiration rates and water relations through in the stressrelated responses and stomatal control. In crops the practices which optimize the fertilization of Mo have significant scope in exploring where the predominant available $\mathrm{N}$ source is $\mathrm{No}_{3}{ }^{-}$or in $\mathrm{N}$ fixing legumes. To predict the Mo geochemical transport in subsurface and surface environments, the distribution and sources of the Mo species of $\mathrm{MoS}_{4}{ }^{2-}$ and $\mathrm{MoO}_{4}{ }^{2-}$ in an aqueous solution are critical information. The significant components, comprising clay, oxides, $\mathrm{Fe}$, iron sulfide, $\mathrm{Al}$, , organic matter and manganese oxides in soils and bed sediments, show different adsorption capacity to Mo.

In our understanding, in plants functions and role of Mo, recent years have conveyed rapid improvement. Obviously, the research concentrates both on the studying relationships of structure-function of the Mo-enzymes and on detailed enzymology of the Moco biosynthesis.

\section{Future prospects}

For NR there is a lot of physiological data, but not for SO, $\mathrm{AO}$ and $\mathrm{XDH}$ and there are, yet, a number of open questions.

I. By member of the AO family what the additional metabolic reactions are catalyzed?

\section{Why SO localized in the peroxisomes?}

III. What is the exact role of SO?

IV. For the MPT synthesis what protein donates the copper?

V. In the plant defense and reactive oxygen metabolism, what is the role of $\mathrm{XDH}$ ? 
VI. Will by the molybdopterin ligand metals other than tungsten or molybdenum be found to be coordinated?

VII. After its release during the Moco formation what protein accepts copper?

VIII. The $\mathrm{CnX} 4$ role is not so much clear, what key roles it has? The molybdate transporter how it is organized? what gene code for molybdate transporter?

IX. For the Moco biosynthesis organized how is the multienzyme complex?

$\mathrm{X}$. For the Moco to meet with regards to changing demands of the cell, how Moco biosynthesis is being regulated?

XI. For the Moco insertion, what is the mechanism behind this that is involved in apo-enzymes?

XII. In some enzymes, what factors influence the incorporation of the tungsten instead of the molybdenum?

XIII. What role is being played by the $\mathrm{Cu}$ in the synthesis of Moco?

XIV. Furthermore, about factors very diminutive is known that are regulatory the interaction of proteins and expression of genes involved in the homeostasis of molybdenum, thus needing advanced comprehensive analysis on metabolome, transcriptome, ionome level, proteome and interactome.

Requires further investigation, the involvement of each cofactor scaffold to the complete chemistry of given enzyme, that the numerous scaffolds represent corridors generating sulfur-containing chelators that can control, trap and activate the transition elements as catalysts. With specialized functions in the eukaryotes some of proteins are the precursors of these, such as ubiquitin-like protein conjugation 64 and the G-protein-based signaling; others, such as the gephyrin, that is crucial for synaptogenesis, have gathered the additional functions.

The coming years perhaps into these will bring deep insight into innovative molybdenum aspects within the physiological and metabolic network of cells. In the field of molybdenum enzymes future research is likely to focus on detailed mechanistic of the functions of cofactors, the cofactor biosynthesis and cofactor allocation in specific enzymes.

\section{References}

1. Rana MS, Bhantana P, Sun XC, Imran M, Shaaban M, et al. (2020) Molybdenum as an Essential Element for Crops: An Overview. Link: https://bit.ly/3d7IdQR

2. Imran M, Hu C, Hussain S, Rana MS, Riaz M, et al. (2019a) Molybdenuminduced effects on photosynthetic efficacy of winter wheat (Triticum aestivum L.) under different nitrogen sources are associated with nitrogen assimilation. Plant Physiology and Biochemistry 141:154-163. Link: https://bit.ly/2UJsyBd

3. Ismael M, Elyamine A, Zhao Y, Moussa M, Rana M, et al. (2018) Can selenium and molybdenum restrain cadmium toxicity to pollen grains in Brassica napus? Int J Mol Sci 19: 2163. Link: https://bit.ly/2N23X6I
4. Rana MS, Hu CX, Shaaban M, Imran M, Afzal J, et al. (2020b) Soil phosphorus transformation characteristics in response to molybdenum supply in leguminous crops. J Environ Manage 268:110610 Link: https://bit.ly/3hww5wv

5. Imran M, Sun X, Hussain S, Ali U, Rana MS, et al. (2019b) Molybdenum-Induced Effects on Nitrogen Metabolism Enzymes and Elemental Profile of Winter Wheat (Triticum aestivum L.) Under Different Nitrogen Sources Int J Mol Sci 20: 3009. Link: https://bit.ly/3d4hvJd

6. Liu $P$ (2001) The research development of molybdenum and boron nutrition in soybean. China Agricultural Science Bulletin 17: 41-44.

7. Liu P, Wu JZ, Yang YA (2000) The research development of boron in soil and its effect in plant. Agri-Environmental Protection 19: 119-122.

8. Rana MS, Sun X, Imran M, Ali S, Shaaban M, et al. (2020c) Molybdenum-induced effects on leaf ultra-structure and rhizosphere phosphorus transformation in Triticum aestivum L. Plant Physiology and Biochemistry 153: 20-29. Link: https://bit.ly/2YOLops

9. Liu P (2002b) Effects of the stress of molybdenum on plants and the interaction between molybdenum and other element. Agri-Environmental Protection. 21: 276-278.

10. Williams RJP, Frausto da Silva JJR (2002) The involvement of molybdenum in life. Biochemical and Biophysical Research Communications 292: 293-299. Link: https://bit.ly/37uBNKs

11. Mendel RR, Haensch R (2002) Molybdoenzymes and molybdenum cofactor in plants. J Exp Bot 53: 1689-1698. Link: https://bit.ly/2Yzgle4

12. Sauer $P$, Frebort I (2003) Molybdenum cofactor-containing oxidoreductase family in plants. Biologia Plantarum 46: 481-490. Link: https://bit.ly/3eaEEeo

13. Self WT, Grunden AM, Hasona A, Shanmugam KT (2001) Molybdate transport. Research in Microbiology 152: 311-321.

14. Yesbergenova Z, Yang G, Oron E, Soffer D, Fluhr R, et al. (2005) The plant Mohydroxylases aldehyde oxidase and xanthine dehydrogenase have distinct reactive oxygen species signatures and are induced by drought and abscisic acid. Plant J 42: 862-876. Link: https://bit.ly/2C1vB0S

15. Schwarz G, Mendel RR, Ribbe MW (2009) Molybdenum cofactors, enzymes and pathways. Nature 460: 839-847. Link: https://bit.ly/2NOlzPT

16. Bittner F, Mendel RR (2010) Cell biology of molybdenum. Cell Biology of Metals and Nutrients 17: 119-143. Link: https://bit.ly/37uWTsl

17. Jiang M, Zhang J (2001) Effect of abscisic acid on active oxygen species, antioxidative defence system and oxidative damage in leaves of maize seedlings. Plant Cell Physiol 42: 1265-1273. Link: https://bit.ly/2YA8K4h

18. Mengel K, Kirkby EA (2001) Principles of Plant Nutrition ( $5^{\text {th }}$ ed.) Dordrecht: Kluwer Academic Publishers 480.

19. Arnon DI, Stout PR (1939) Molybdenum as an essential element for higher plants. Plant Physiol 14: 599-602. Link: https://bit.ly/3huyzvm

20. Fido RJ, Gundry CS, Hewitt EJ, Notton BA (1977) Ultrastructural features of molybdenum deficiency and whiptail in cauliflower leaves: effects of nitrogen source and tungsten substitution for molybdenum. Aust J Plant Physiol 4: 675-689. Link: https://bit.ly/3efTGiE

21. Gasber A, Klaumann A, Trentmann O, Trampczynska A, Clemens S, et al. (2011) Identification of an Arabidopsis solute carrier critical for intracellular transport and interorgan allocation of molybdate. Plant Biol 13: 710-718. Link: https://bit.ly/2CaAvsH

22. Kaiser BN, Gridley KL, Brady JN, Phillips T, Tyerman SD (2005) The role of molybdenum in agricultural plant production. Ann Bot 96: 745-754. Link: https://bit.ly/37woMQy 
23. Baxter I, Muthukumar B, Park HC, Buchner P, Lahner B, et al. (2008) Variation in molybdenum content across broadly distributed populations of Arabidopsis thaliana is controlled by a mitochondrial molybdenum transporter (MOT1). PLoS Genet 4:e1000004. Link: https://bit.ly/3d7R84N

24. Muller AJ, Mende RR (1989) Biochemical and somatic cell genetics of nitrate reductase in Nicotiana. In: Wray JL, Kinghorn JR (eds) Molecular and genetic aspects of nitrate assimilation. Oxford University Press Oxford 166-185.

25. Seo M, Peeters AJ, Koiwai H, Oritani T, Marion-Poll A, et al. (2000) The Arabidopsis aldehyde oxidase 3 (AAO3) gene product catalyzes the final step in abscisic acid biosynthesis in leaves. Proc Natl Acad Sci USA 97: 1290812913. Link: https://bit.ly/3fiQa7w

26. Seo M, Koiwai H, Akaba S, Komano T, Oritani T, et al. (2000a) Abscisic aldehyde oxidase in leaves of Arabidopsis thaliana. Plant J 23: 481-488. Link: https://bit.ly/2MWwIXz

27. Lang C, Popko J, Wirtz M, Hell R, Herschbach C, et al. (2007) Sulphite oxidase as key enzyme for protecting plants against sulphur dioxide. Plant Cell Environ 30: 447-455. Link: https://bit.ly/2YDfUos

28. Xiong L, Ishitani M, Lee $\mathrm{H}$, Zhu JK (2001) The arabidopsis los5/aba3 locus encodes a molybdenum cofactor sulfurase and modulates cold stress- and osmotic stress-responsive gene expression. Plant Cell 13: 2063-2083. Link: https://bit.ly/37tzN5p

29. Xu N, Christodoulatos C, Braida W (2006) Adsorption of molybdate and tetrathiomolybdate onto pyrite and goethite: Effect of $\mathrm{pH}$ and competitive anions. Chemosphere 62: 1726-1735. Link: https://bit.ly/3hqMdPY

30. Elyamine AM, Afzal J, Rana MS, Imran M, Cai M, et al. (2018) Phenanthrene Mitigates Cadmium Toxicity in Earthworms Eisenia fetida (Epigeic Specie) and Aporrectodea caliginosa (Endogeic Specie) in Soil. Int J Environ Res Public Health 15: 2384. Link: https://bit.ly/2Y37I1N

31. Elyamine AM, Moussa MG, Afzal J, Rana MS, Imran M, et al. (2019) Modified Rice Straw Enhanced Cadmium (II) Immobilization in Soil and Promoted the Degradation of Phenanthrene in Co-Contaminated Soil. Int J Mol Sci 20: 2189. Link: https://bit.ly/3dZIrvX

32. Afzal J, Hu C, Imtiaz M, Elyamine A, Rana M, et al. (2019) Cadmium tolerance in rice cultivars associated with antioxidant enzymes activities and $\mathrm{Fe} / \mathrm{Zn}$ concentrations. Int J Environ Techn 16: 4241-4252. Link: https://bit.ly/2ACjDKU

33. Van Zwieten M, Bashir S, Younas A, Núñez-Delgado A, Chhajro MA, et al. (2018) A concise review of biochar application to agricultural soils to improve soil conditions and fight pollution. J Environ Manage 228:429-440. Link: https://bit.ly/2MXt9dZ

34. Yaseen R, Shafi J, Ahmad W, Rana MS, Salim M, et al. (2014) Effect of deficit irrigation and mulch on soil physical properties, growth and yield of maize. Environ Ecol Res 2: 122-137. Link: https://bit.ly/3d5eAQq

35. Murtaza Z, Ahmad W, Shafi J, Shoaib M, Sarwar MA, et al. (2013) Effect of Prolonged Irrigated Fodders on Soil Physical Properties and Agronomic Water Use Efficiency. Natural Resources and Conservation 1: 77-93. Link: https://bit.ly/2C9Kv5q

36. Goldberg S, Forster HS (1998) Factors affecting molybdenum adsorption by soils andminerals. Soil Sci 163: 109-114. Link: https://bit.ly/3d0hA01

37. Carroll KC, Artiola JF, Brusseau ML (2006) Transport of molybdenum in a biosolid amended alkaline soil. Chemosphere 65: 778-785. Link: https://bit.ly/2AFilt3

38. Kabata-Pendias A (2004) Soil-plant transfer of trace elements-an environmental issue. Geoderma 122: 143-149. Link: https://bit.ly/30PCRY|

39. Nagajyoti PC, Lee KD, Sreekanth TVM (2010) Heavy metals, occurrence and toxicity for plants: a review. Environ Chem Lett 8: 199- 216. Link: https://bit.ly/2YAtIQC
40. McGrath SP, Mico C, Zhao FJ, Stroud JL, Zhang H, et al. (2010) Predicting molybdenum toxicity to higher plants: estimation of toxicity threshold values. Environ Pollut 158: 3085-3094. Link: https://bit.ly/2BbTvX2

41. Reddy KJ, Munn LC, Wang L (1997) Chemistry and mineralogy of molybdenum in soils. Molybdenum in agriculture 4-22.

42. Jiang $W$, Zhongfang $Y$, Tao $Y$, Qingye $H$, Cong Z, et al. (2015) Evaluation of the potential effects of soil properties on molybdenum availability in soil and its risk estimation in paddy rice. J Soils Sediments 15: 1520-1530. Link: https://bit.ly/2Y3QUrb

43. Goldberg S, Forster HS, Godfrey CL (1996) Molybdenum adsorption on oxides, clay minerals and soils. Soil Sci Soc Am J 60: 425-432. Link: https://bit.ly/3e59dC2

44. Lang F, Pohlmeier A, Kaupenjohann M (2000) Mechanism of molybdenum sorption to iron oxides using pressure-jump relaxation. J. Plant Nutr Soil Sci 163: 571-575. Link: https://bit.ly/3d5tDtp

45. Arai Y (2010) X-ray absorption spectroscopic investigation of molybdenum multinuclear sorption mechanism at the geothite-water interface. Environ Sci Technol 44: 8491-8496. Link: https://bit.ly/3fvtGAl

46. Erickson BE, Helz GR (2000) Molybdenum(VI) speciation in sulfidic waters: Stability and lability of thiomolybdates. Geochim Cosmochim Acta 64: 11491158. Link: https://bit.ly/2Y2WXfF

47. Paktunc AD, Dave NK (2002) Formation of secondary pyrite and carbonate minerals in the Lower Williams Lake tailing basin, Elliot Lake, Ontario, Canada. Am Mineralogist 87: 593-602. Link: https://bit.ly/2B4PJyN

48. Adelson JM, Helz GR, Miller CV (2001) Reconstructing the rise of recent coastal anoxia: Molybdenum in Chesapeake Bay Sediments. Geochim. Cosmochim. Acta 65: 237-252. Link: https://bit.ly/2N0OhQU

49. Helz GR, Bura-Naki' E, Mikac N, Ciglenecki I (2011) Newmodel for molybdenum behavior in euxinic waters. Chem Geol 284: 323-332. Link https://bit.ly/37wrFRr

50. Helz GR, Vorlicek TP, Kahn MD (2004) Molybdenum scavenging by iron monosulfide. Environ Sci Technol 38: 4263-4268. Link: https://bit.ly/3flAiRu

51. Bostick BC, Fendorf S, Helz GR (2003) Differential adsorption of molybdate and tetrathiomolybdate on pyrite (FeS2). Environ Sci Technol 37: 285-291. Link: https://bit.ly/30lk80x

52. Vorlicek TP, Kahn MD, Kasuya Y, Helz GR (2004) Capture of molybdenum in pyriteforming sediments: Role of ligand-induced reduction by polysulfides. Geochimica et Cosmochimica Acta 68: 547-556. Link: https://bit.ly/2NONLIW

53. Wu CH, Lo SL, Lin CF (2000) Competitive adsorption of molybdate, chromate sulfate, selenate, and selenite on Y -Al203. Colloids and Surfaces A Physicochemical and Engineering Aspects 166: 251-259.

54. Wu CH, Lo SL, Lin CF, Kuo CY (2001) Modeling competitive adsorption of molybdate, sulfate, and selenate on Y -Al2O3 by the Triple-Layer model. $J$ Colloid Inter Sci 233: 259-264. Link: https://bit.ly/30PvdND

55. Bard AJR, Parson Jordan J (1985) Standard Potentials in Aqueous Solutions Marcel Dekker, New York. Link: https://bit.ly/3e52yrA

56. Mitchell, P. C. H. 1990. Molybdenum and molybdenum compounds. In Ullmann's Encyclopedia of Industrial Chemistry, 5th ed., A16, Chap. 7, pp. 675-682. Wiley-VCH GmbH \& Co. KGaA, Weinheim, Germany.

57. Adriano DC (1986) Trace Elements in the Terrestrial Environment, SpringerVerlag, New York. Link: https://bit.ly/3ehV1FG

58. Brookins DG (1987) Eh-pH Diagrams for Geochemistry, Springer-Verlag, New York.

59. Reddy KJ, Gloss SP (1993) Geochemical speciation as related to the

Citation: Rana MS, Bhantana P, Imran M, Saleem MH, Chengxiao Hu, et al. (2020) Molybdenum potential vital role in plants metabolism for optimizing the growth and development. Ann Environ Sci Toxicol 4(1): 032-044. DOI: https://dx.doi.org/10.17352/aest.000024 
mobility of F, Mo and Se in soil leachates. Appl Geochem 8: 159-163. Link: https://bit.ly/2B9qnQk

60. Bortels H (1930) Molybda"n als Katalysator bei der biologischen Stickstoffbindung. Arch Mikrobiol 1: 333-342.

61. Mendel RR, Schwarz G (2011) Molybdenum cofactor biosynthesis in plants and humans. Coord Chem Rev 255: 1145-1158. Link: https://bit.ly/2Y2NvZU

62. Turnlund JR (2002) Molybdenum metabolism and requirements in humans. Met lons Biol Syst 39: 727-739. Link: https://bit.ly/2NelWXr

63. Shinmachi F, Buchner P, Stroud JL, Parmar S, Zhao FJ, et al. (2010) Influence of sulfur deficiency on the expression of specific sulfate transporters and the distribution of sulfur, selenium, and molybdenum in wheat. Plant Physiol 153 327-336. Link: https://bit.ly/37CdYRg

64. Mendel RR (2013) The molybdenum cofactor. J Biol Chem 288: 13165-13172. Link: https://bit.ly/30MHL8s

65. Ide $Y$, Kusano M, Oikawa A, Fukushima A, Tomatsu H, et al. (2011) Effects of molybdenum deficiency and defects in molybdate transporter MOT1 on transcript accumulation and nitrogen/sulphur metabolism in Arabidopsis thaliana. J Exp Bot 62: 1483-1497. Link: https://bit.ly/2YCjdMB

66. Mendel RR (2011) Cell biology of molybdenum in plants. Plant cell Rep 30: 1787-1797. Link: https://bit.ly/2N0W7tx

67. Wiedenhoeft AC (2006) Plant Nutrition (The Green World). By Infobase Publishing. 132 West 31st Street New York NY 10001

68. Allen RM, Roll JT, Rangaraj P, Shah VK, Roberts GP, et al. (1999) Incorporation of molybdenum into the iron-molybdenum cofactor of nitrogenase. $\mathrm{J}$ Bio Chem 274: 15869-15874. Link: https://bit.ly/3hrV9Vb

69. Brodrick SJ, Giller KE (1991) Genotypic difference in molybdenum accumulation affects $\mathrm{N}$; fixation in tropical Pharsalus vulgaris. J Exp Bot 42 1339-1343. Link: https://bit.ly/30G7FKV

70. Dilworth MJ, Loneragan JE (1991) An alternative nitrogenase is not expressed in molybdenum-deficient legume root nodules. New Phytol 118: 303-308. Link: https://bit.ly/2UMp4hd

71. Delgado MJ, Tresierra-Ayala A, Talbi C, Bedmar EJ (2006) Functiona characterization of the Bradyrhizobium japonicum modA and modB genes involved in molybdenum transport. Microbiology 152: 199-207. Link: https://bit.ly/2YCDEZJ

72. Yanni YG (1992) Performance of chickpea, lentil and lupin nodulated with indigenous or inoculated rhizobia micropartners under nitrogen, boron, cobalt and molybdenum fertilization schedules. World J Microbiol Biotechnol 8: 607613. Link: https://bit.ly/2ULz4XY

73. Vieira RF, Cardoso EJBN, Vieira C, Cassini STA (1998) Foliar application of molybdenum in common beans. I. Nitrogenase and reductase activities in a soil of high fertility. J Plant Nutr 21: 169-180. Link: https://bit.ly/3e7ZZEX

74. Younge OR, Takahashi M (1953) Response ofalfalfa to molybdenum in Hawaii. Agron J 45: 420-428.

75. Pau RN, Lawson DM (2002) Transport, homeostasis, regulation, and binding of molybdate and tungstate to proteins. Met Ions Biol Syst 39: 39-74. Link: https://bit.ly/37FKp1a

76. Tomatsu H, Takano T, Takahashi H, Watanabe-Takahashi A, Shibagaki N, et al (2007) An Arabidopsis thaliana high-affinity molybdate transporter required for efficient uptake of molybdate from soil. Proc Natl Acad Sci USA 104: 1880718812. Link: https://bit.ly/2YGWpuW

77. Tejada-Jimenez M, Galvan A, Fernandez E (2011) Algae and humans share a molybdate transporter. Proc Natl Acad Sci USA 108: 6420-6425. Link: https://bit.ly/2UNwHUE
78. Fitzpatrick KL, Tyerman SD, Kaiser BN (2008) Molybdate transport through the plant sulfate transporter SHST1. FEBS Lett 582: 1508-1513. Link: https://bit.ly/37zij7N

79. Shibagaki N, Grossman AR (2006) The role of the STAS domain in the function and biogenesis of a sulfate transporter as probed by random mutagenesis. $J$ Biol Chem 281: 22964-22973. Link: https://bit.ly/2zAb7LU

80. Tejada-Jimenez M, Llamas A, Sanz-Luque E, Galvan A, Fernandez E (2007) A high-affinity molybdate transporter in eukaryotes. Proc Natl Acad Sc U.S.A 104: 20126-20130. Link: https://bit.ly/3d7ne0y

81. Ramesh $\mathrm{K}$, Thirumurugan $\mathrm{V}$ (2001) Effect of seed pelleting and foliar nutrition on growth of soybean. Madras Agric J 88: 465-468. Link:

82. Biscaro GA, Goulart SAR, Soratto PR, Freitas-Júnior NA, Motomiya AVA, et al. (2009) Molybdenum applied to seeds and side dressing nitrogen on irrigated common bean in cerrado soil. Ciênc Agrotec 33: 1280-1287. Link: https://bit.ly/37yv0iV

83. Rhodes ER, Nangju D (1979) Effects of pelleting cowpea and soybean seed with fertilizer dusts. Exp Agric 15: 27-32. Link: https://bit.ly/3hweQeu

84. Burton JC, Curley RL (1966) Compatibility of Rhizobium japonicum and sodium molybdate when combined in a peat carrier medium. Agron J 58: 327-330.

85. Martin G, Fourrier P (1965) Les oligo-éléments dans la culture de l'arachide du Nord Sénégal. Olèagineux 20: 287-291. Link: https://bit.ly/2N2TcRm

86. Haque I, Amara DS (1978) Effects of inoculation and sodium molybdate on groundnuts. Trop Grain Legumes Bull 11/12: 11-12.

87. Rhodes ER, Kpaka M (1982) Effects of nitrogen, molybdenum and cultivar on cowpea growth and yield on an Oxisol. Commun Soil Sci Plant Anal 13: 279 283. Link: https://bit.ly/2N2ySzi

88. Albino UB, Campo RJ (2001) Efeito de fontes e doses de molibdenio na sobrevive ncia do Bradyrhizobium e na fixacao biologica de nitrogenio em soja. Pesq Agro Bras 36: 527-534. Link: https://bit.ly/3d2gUYt

89. Campo RJ, Albino UB, Hungria M (2000) Importance of molybdenum and cobalt to the biological nitrogen fixation. In: F.O. Pedrosa, M. Hungria, G. Yates, W.E. Newton (eds.). Nitrogen Fixation: From Molecules to Crop Productivity Springer, Netherlands 597- 598. Link: https://bit.ly/2Ylato2

90. Donald CM, Spencer D (1951) The control of molybdenum deficiency in subterranean clover by pre-soaking the seed in sodium molybdate solution. Australian J Agric Res 2: 295-301. Link: https://bit.ly/3ftNGTP

91. Johansen C, Musa AM, Kumar Rao JVDK, Harris D, Shahidullah AKM, et al. (2006) Seed priming with molybdenum alleviates molybdenum deficiency and poor nitrogen fixation of chickpea in acid soils of Bangladesh and India In 18th World Congress of Soil Science, Philadelphia, Pennsylvania, USA. Link: https://bit.ly/3hyJgN9

92. Malla RM, Padmaja B, Malathi S, Jalapathi RL (2007) Effects of micronutrients on growth and yield of pigeonpea. J Semi-Arid Trop Agric Res 5: 1-3. Link: https://bit.ly/3e7BWGe

93. Mohandas S (1985) Effect of presowing seed treatment with molybdenum and cobalt on growth, nitrogen and yield in bean (Phaseolus vulgaris L.). Plant Soil 86: 283-285. Link: https://bit.ly/3d6vCNO

94. Kumar Rao JVDK, Harris D, Johansen C, Musa AM (2004) Low cost provision of molybdenum (Mo) to chickpeas grown in acid soils. In: Proceedings of the Zvarevashe, CARE Stakeholder Workshop, Report IDG/00/18, Silsoe Research Institute, Bedford, UK

95. Khanal N, Joshi D, Harris D, Chand SD (2005) Effect of micronutrient loading soil application, and foliar sprays of organic extracts on grain legumes and vegetable crops under marginal farmers' conditions in Nepal. In: P. Andersen, J.K. Tuladhar, K.B. Karki, S.L. Maskey (eds.). Micronutrients in South and South East Asia, pp. 121-132. Proceedings of an International Workshop

Citation: Rana MS, Bhantana P, Imran M, Saleem MH, Chengxiao Hu, et al. (2020) Molybdenum potential vital role in plants metabolism for optimizing the growth and development. Ann Environ Sci Toxicol 4(1): 032-044. DOI: https://dx.doi.org/10.17352/aest.000024 
held in Kathmandu, Nepal, 8-11 September, 2004. The International Centre for Integrated Mountain Development, Kathmandu,Sri Lanka. Link: https://bit.ly/2ULGIBR

96. Johansen C, Musa AM, Kumar Rao JVDK, Harris D, Ali MY, et al. (2006) Correcting molybdenum deficiency of chickpea in the high barind tract of Bangladesh. J Plant Nutr Soil Sci 170: 752-761.

97. Pattanayak SK, Dash V, Jena MK, Nayak RK (2000) Seed treatment of green gram with molybdenum and cobalt: effect on nodulation, biomass production and $\mathrm{N}$ uptake in an acid soil. J Ind Soc Soil Sci 48: 769-773. Link: https://bit.ly/3e7GuMK

98. Haque I, Bundu HS (1980) Effects of inoculation, nitrogen, molybdenum and mulch on soybean in Sierra Leone. Commun Soil Sci Plant Anal 11: 477-483. Link: https://bit.ly/3d8aved

99. Katyal JC, Randhawa NS (1983) Micronutrients (molybdenum). FAO Fert. Plant Nutr Bull 7: 69-76. Link: https://bit.ly/2UNO8nW

100. Valenciano JB, Marcelo V, Miguelez-Frade MM (2011) Effect of different times and techniques of molybdenum application on chickpea (Cicer arietinum) growth and yield. Span J Agric Res 9: 1271-1278. Link: https://bit.ly/3fmQ7Ye

101. Boaretto AE, Muraoka T, Boaretto RM (2003) Absorção e translocação de Mn, Zn e B Aplicados via foliar em Citros. Laranja 24: 177-197.

102. Campo RJ, Hungria M (2002) Importância dos micronutrientes na fixação biológica do N2. Informações Agronômicas 98: 6-9.

103. Biscaro GA, Freitas-Junior NA, Soratto RP, Kikuti H, Goulart SAR, et al. (2011) Nitrogênio em cobertura e molibdênio via foliar no feijoeiro irrigado cultivado em solo de cerrado. Acta Sci Agron 33: 665-670. Link: https://bit.ly/3d0vfVa

104. Toledo MZ, Garcia RA, Pereira MRP, Boaro CSF, Lima GPP (2010) Nodulação e atividade da nitrato redutase em função da aplicação de molibdênio em soja. Biosci J 26: 858-864. Link: https://bit.ly/2UJqR6E

105. Calonego JC, Ramos EU, Barbosa RD, Leite GHP, Grassi FH (2010) Adubação nitrogenada em cobertura no feijoeiro com suplementação de molibdênio via foliar. Rev Ciênc Agron 41: 334- 340. Link: https://bit.ly/2N0tl6Z

106. Lombin G, Singh L, Yayock JY (1985) A decade of fertilizer research on groundnuts in the savanna zone of Nigeria. Fert Res 6: 157-170. Link: https://bit.ly/2CbU3gg

107. Kang BT, Osiname OA (1985) Micronutrient problems in tropical Africa. Fert Res 7: 131-150. Link: https://bit.ly/3e4wkfW

108. Tanner PD (1982) The molybdenum requirements of maize in Zimbabwe Zimbabwe Agric J 79: 61-64.

109. Ruiz JM, Rivero R, Romero ML (2007) Comparative effect of Al, Se, and Mo toxicity on NO3- assimilation in sunflower (Helianthus annuus L.) plants. J Environ Manage 83: 207-212. Link: https://bit.ly/2AEvbxe

110. Gupta UC, Macleod JA (2006) Boron and molybdenum. In: Encyclopedia of soil science. Second edition, Taylor and Francis 188-190.

111. Brennan RF, Bolland MDA (2007) Increased concentration of molybdenum in sown wheat seed decreases grain yield responses to applied molybdenum fertilizer in naturally acidic sandplain soils. J Plant Nutr 30: 2005-2019. Link: https://bit.ly/2AEtXCa
112. Balik JD, Pavlikowa P, Cerny TJ, Kulhanek M (2007) The content of molybdenum in oilseed rape plants after the application of nitrogen and sulphur fertilizers. In: Biogeochemistry of trace elements: Environmental protection, remediation and human health. Eds. Y. Zhu, N. Lepp, R. Naidu, Tsinghua University Press, Bei Jing, 46-47.

113. Shorrocks RM (1984) Micronutrients and their use world wide. Fertilizer 1 : 63-85.

114. Parish DH, Vignes EC, Cavalot C, Abel M (1965) Trace elements status of sugar-cane in Mauritius. Report of the Mauritius Sugar Industry Research Institute 12: 60-61.

115. Vieira RF, Salgado LT, De AC, Ferreir AB (2005) Performance of Common Bean using seeds harvested from plants fertilized with high rates of molybdenum. J Plant Nutr 28: 363-377. Link: https://bit.ly/3hqXAYh

116. Tanner PD (1976) Manganese toxicity and molybdenum deficiency effects on maize grown in an acid fersialllitic red sandy clay loam. Rhod J Agric Res 14: 95

117. Tanner PD, Grant PM (1977) Response of maize to lime and molybdenum on acid red and yellow-brown clay loams. Rhod J Agric Res 15: 143-149.

118. Caboch M, Campell WH, Crawford NM, Fernandez E, Kleinhops A, et al. (1994) Genes involved in nitrogen assimilation. Plant Molecular Bio Reporter 12: 45-49.

119. Haque I, Bundu HS (1980) Effects of inoculation, nitrogen, molybdenum and mulch on soybean in Sierra Leone. Commun Soil Sci Plant Anal 11: 477-483. Link: https://bit.ly/3d8aved

120. Hille R (2002) Molybdenum enzymes containing the pyranopterin cofactor an overview. Met lons Biol Syst 39: 187-226. Link: https://bit.ly/3e5GUmR

121. IITA (International Institute of Tropical Agriculture) (1975) Study on micronutrients. 1. Molybdenum response in cowpea. In: Annual Report. IITA, Ibadan, Nigeria. 20.

122. Johnson SE, Lauren JG, Welch RM, Duxbury JM (2005) A comparison of the effects of micronutrient seed priming and soil fertilization on the mineral nutrition of chickpea (Cicer arietinum), lentil (Lens culinaris), rice (Oryza sativa) and wheat (Triticum aestivum) in Nepal. Exper Agric 41: 427-448. Link: https://bit.ly/3hwgOLU

123. Mendel RR (2009) Cell biology of molybdenum. Bio Factors 35: 429-434 Link: https://bit.ly/2Bc6pEJ

124. Rana MS, Bhantana P, Sun XC, Imran M, Shaaban M, et al. (2020a) Molybdenum as an Essential Element for Crops: An Overview. Link: https://bit.ly/3d7IdQR

125. Rana MS, Murtaza G, Hu C, Sun X, Imran M, et al. (2020) Nitrate leaching losses reduction and optimization of $\mathrm{N}$-use efficiency in Triticum aestivum L. Aand Oryza sativa L. crop rotation for enhancing crop productivity. Pak J Agri Sci 57: 645-653.

126. Xu N, Washington B, Christos C, Jianping C (2013) A review of molybdenum adsorption in soils/bed sediments: speciation, mechanism, and mode applications. Soil and Sediment Contamination: An International Journal 22: 912-929, Link: https://bit.ly/3d4KJaN

127. Carter C, Pan S, Zouhar J, Avila EL, Girke T, et al. (2004) The vegetative vacuole proteome of Arabidopsis thaliana reveals predicted and unexpected proteins. Plant Cell 16: 3285-3303. Link: https://bit.ly/2Bc5XGx

Copyright: (c) 2020 Rana MS, et al. This is an open-access article distributed under the terms of the Creative Commons Attribution License, which permits unrestricted use, distribution, and reproduction in any medium, provided the original author and source are credited.

Citation: Rana MS, Bhantana P, Imran M, Saleem MH, Chengxiao Hu, et al. (2020) Molybdenum potential vital role in plants metabolism for optimizing the growth and development. Ann Environ Sci Toxicol 4(1): 032-044. DOI: https://dx.doi.org/10.17352/aest.000024 